\title{
New Record of Leptocybe invasa Fisher and La Salle (Hymenoptera: Eulophidae) on the White Gum in Timor Tengah Selatan District, East Nusa Tenggara Province, Indonesia
}

\author{
Lindung Tri Puspasari ${ }^{1}$, Damayanti Buchori ${ }^{2}$, Rosichon Ubaidillah ${ }^{3}$, Hermanu \\ Triwidodo $^{2}$, Purnama Hidayat ${ }^{2} *$ \\ ${ }^{I}$ Study Program of Entomology, Graduate School, Faculty of Agriculture, IPB University \\ ${ }^{2}$ Department of Plant Protection, Faculty of agriculture, IPB University \\ ${ }^{3}$ Indonesian Institute of Science \\ *Corresponding author.Email: phidayat@apps.ipb.ac.id
}

\begin{abstract}
The eucalyptus gall wasp, Leptocybe invasa Fisher \& La Salle (Hymenoptera: Eulophidae) was identified for the first time on the white gum Eucalyptus alba Reinw. ex Blume (Myrtaceae) or known as ampupu in the Timor Tengah Selatan District, East Nusa Tenggara Province, Indonesia. Identification is based on the characteristics of the gall morphotype and the morphological character of the insects that emerge from the eucalyptus gall. Morphologically identified insects were confirmed based on molecular characters. Identification based on molecular characteristics using 28S DNA sequence shows $100 \%$ homology with L. invasa DNA sequences deposited in GenBank (accession \# KP143987.1) The eucalyptus gall wasp, L. invasa, causes gall formation on the twigs, young branches and stems on the white gum trees. L. invasa is considered one of the most dangerous gall inducer on eucalyptus. This finding contributes important data for the implementation of pest management in the eucalyptus forest industry in Indonesia.
\end{abstract}

Keywords: gall wasp, invasive insects, Leptocybe invasa, Myrtaceae, lesser sunda

\section{INTRODUCTION}

Eucalyptus is one of the priority plant species for Industrial Plantations because of its adaptability to tropical and subtropical climates. This plant is generally native to Australia, the Philippines, Papua New Guinea and Indonesia [1]. Attacks from gall-forming insects are one of the problems in eucalyptus plants. These pests damage plants by forming a distinctive lump called a gall. Gall is an abnormal form of swelling that causes enlargement of the cells or plant tissue beyond its normal size. The blue gum chalcid, Leptocybe invasa Fischer and La Salle 2004 (Hymenoptera: Eulophidae), is a gall-forming insect that originated from Australia and was first noticed as a pest on eucalyptus in the Mediterranean and Middle East in 2000 [2]. This pest has spread to many countries including Cambodia, China, India, Iran, Malaysia, Sri Lanka, Taiwan, Thailand, Turkey and Vietnam [3]. This insect has become a relevant pest for eucalypt forestry worldwide. Various eucalypt species such as $E$. camaldulensis (var. Camaldulensis and obtusa), $E$. grandis, E. robusta and E. tereticornis show very high susceptibility to blue gum chalcid [3-5] and have been confirmed to be the most susceptible to L. invasa [6]. $L$. invasa are well known for its aggressiveness in attacks and rapid dispersion [7]. The objective of this work is to report the presence of $L$. invasa in Indonesia and the first note of Eucalyptus alba as its host.

\subsection{Related Work}

Eucalyptus galls are collected from $E$. alba plantation in Soe reforestation area, Timor Tengah Selatan District, East Nusa Tenggara Province (9 $9^{\circ} 0^{\prime} 59^{\prime}$ 'S; 124 $16^{\prime} 20^{\prime}$ 'E) (Figure 1) from October 2017 to June 2018. The shape, colour, and gall location on the plant was observed and documented using camera Fuji XA3. Galls were removed from the host plant and transported to the laboratory. Observation was done under the stereo microscope Leica M250 C to determine the type of gall and its size. All collected insect galls were deposited at IPB University, Bogor and Museum Zoologicum Bogoriense, Indonesian Institute of Sciences as the voucher specimens. 


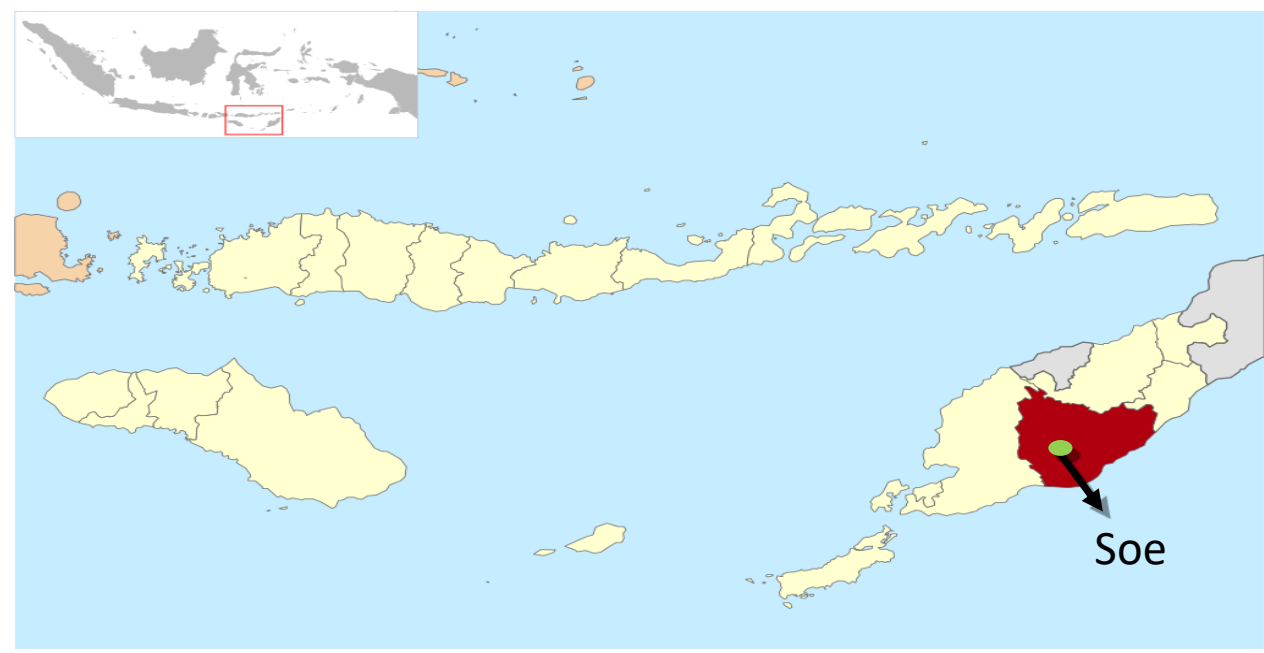

Figure 1 The location for gall eucalypt collection in Soe reforestation garden

\subsubsection{Insect identification}

Collected insects were preserved in tubes containing $70 \% \mathrm{EtOH}$. Insects were identified based on morphological characteristics performed under the Olympus SZ51 stereo microscope as well as on the Leica M205C microscope along with the Leica DFC450 digital camera and the LAS V.4.4.0 (Build: 454) application that is connected to a PC computer. Identification of morphology based on Mendel literature [5]. The identification will also be done using molecular technique based on the DNA sequence of CO-I.

\subsection{Our Contribution}

This paper presents the first report of the L. invasa insect as a cause of gall on eucalyptus plants in East Nusa Tenggara Province, Indonesia, based on morphological characters and has been molecularly confirmed. This finding also implies that special precautions are needed for the eucalyptus forest industry on other islands such as Java, Sumatra, and Kalimantan where these insects still do not exist.

\subsection{Paper Structure}

The rest of the paper is organized as follows. Section 2 introduces the preliminaries used in this paper, which includes collecting symptoms of the eucalyptus plant, describing the gall symptoms and shape of the gall. The symptomatic leaves and branches are taken and stored in plastic containers so that the observed insects come out. Identifying morphologically based on related literature and comparing it with Mendel et al. [2], Doganlar [8] and confirm it with molecular identification. Finally, Section 3 concludes the paper and presents direction for future research

\section{BACKGROUND}

Leptocybe invasa is a novel forest pest responsible for significant economic loss in Eucalyptus spp. plantations worldwide. L. invasa was not identified when it was first recorded in Turkey [9] and Italy in 2001 as Aprostocetus sp. [10]. Simultaneously, severe damage to eucalyptus plantations in Israel and the economic losses that resulted from this pest led to the study of the unknown eulophid wasp-causing gall on eucalypts [2].

Wasp specimens (Figure 2) were identified in insect biosystematics laboratory, Faculty of Agriculture, IPB University with the scientific name L. invasa, by comparing the descriptions given by Mendel et al. [2]. The length of female wasp ranged from 1.1-1.44 mm with a body and head size larger than the males (Figure 2a, 2b). Body length of male ranged from $0.78-1.23 \mathrm{~mm}$; mesosoma brown with metallic shine (blue or dark green); metasoma brown with a slight metallic hint on the dorsal portion. Prothorax is short; well-developed mesothorax; scutellum divided into three separated zones by sublateral lines (Figure 2c). Wings hyaline with yellow veins. Hyaline wings completely covered with setae and slight wing venation. Post marginal vein is shorter than stigmal vein. Submarginal vein generally with 3-4 dorsal setae. Scutelum with submedian and sublateral lines (Figure 2c). Original and detailed description is available in Doganlar [8].

The male antennae are covered with longer hairs compared to the female (Figure 3a, 3b). The male antennae with yellow scape become darker dorsally in the apex and ventral plaque. Pedicellus is yellow, with a darker dorsal basal portion, and a club yellow funicle. The scape is longer than the pedicellum with broadened middle section. Flagellum with six segments separated by four annelli, the basal segments constitute a funiculum and three apical segments form the antennal mass (Figure $3 b$ ). 

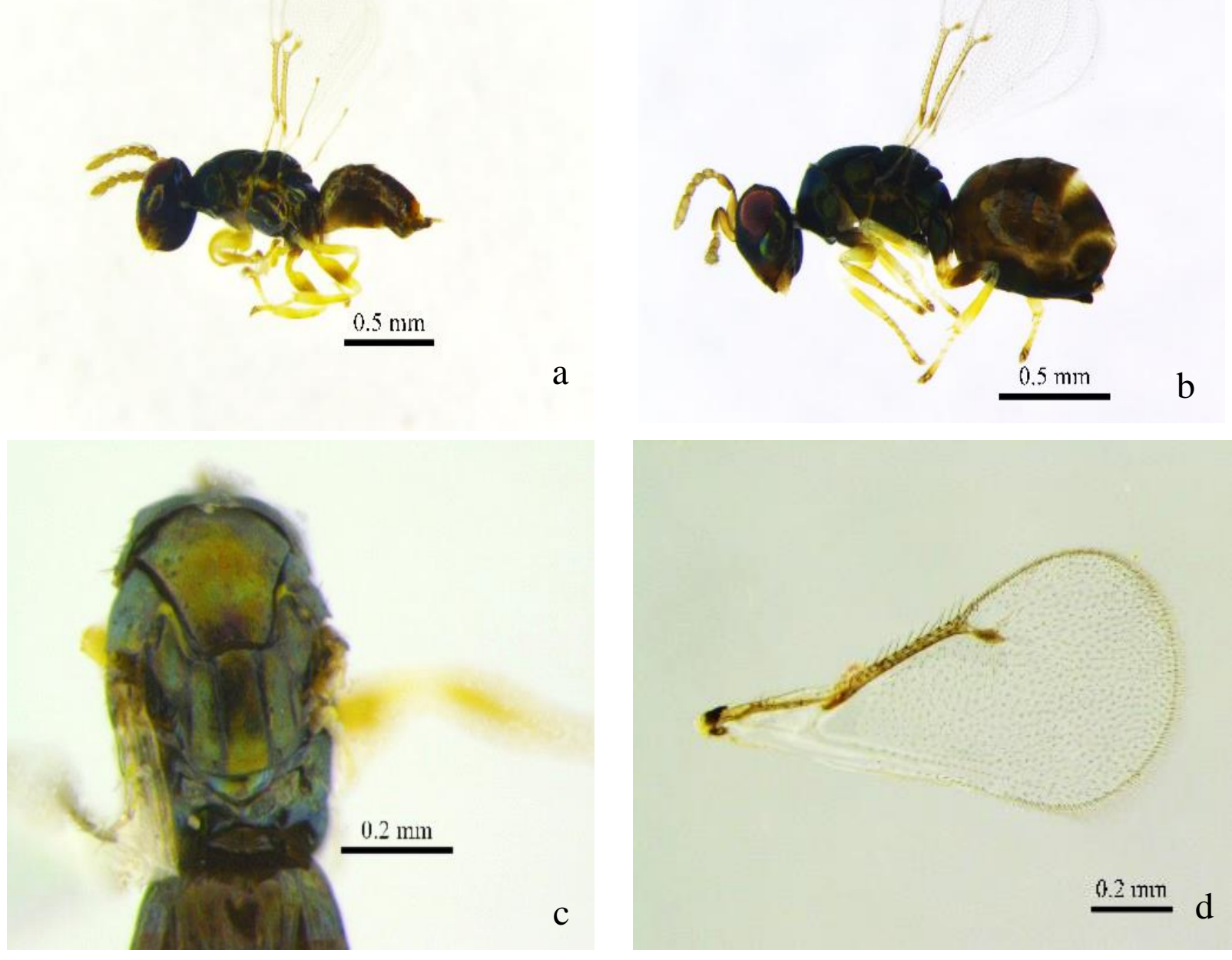

Figure 2 Morphology of L. invasa: (a) male, (b) female, (c) mesosoma dorsal, (d) forewing
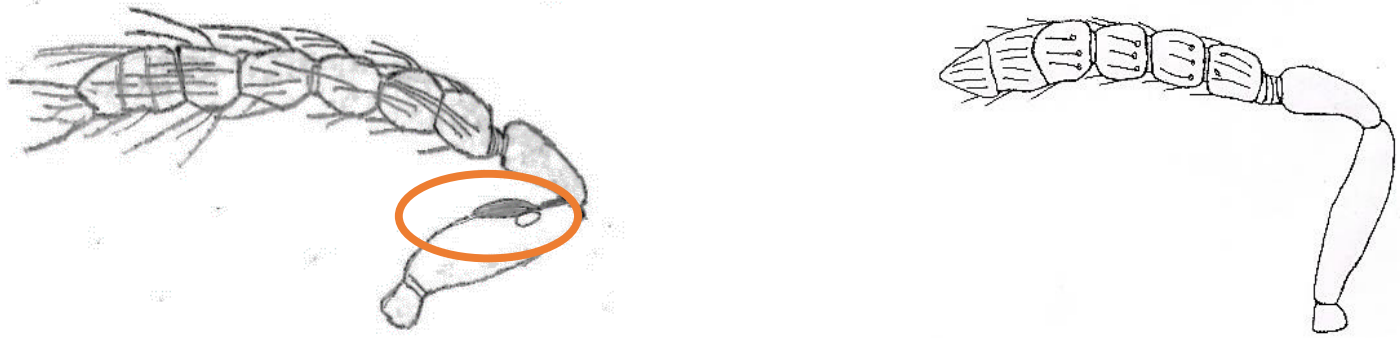

$0.2 \mathrm{~mm}$

Figure 3 Morphology L. invasa: (a) antenna male, (b) antenna female 
caused by L. invasa in E. alba is 1-84 gall with an average per leaf of 3. 17 gall. The gall is oval shaped at the top and bottom of the leaf surface. While on the stems and twigs, the gall formed by this insect is malformed with a length of $0.5-22 \mathrm{~cm}$. The identification based on molecular character utilized 28S DNA sequences with primers D2 3549 (5'AGT CGT GTT GCT TGA TAG TGC AG-3') and D2 4068 (5'-TTG GTC CGT GTT TCA AGA CGG G-3') showing $100 \%$ homology with the $L$. invasa DNA sequences deposited in GenBank (accession \# KP143987.1). It is the sister group of $L$. invasa originating from China (Figure 5). insects.

In Soe reforestation area, Timor Tengah Selatan District, East Nusa Tenggara Province, the number of gall
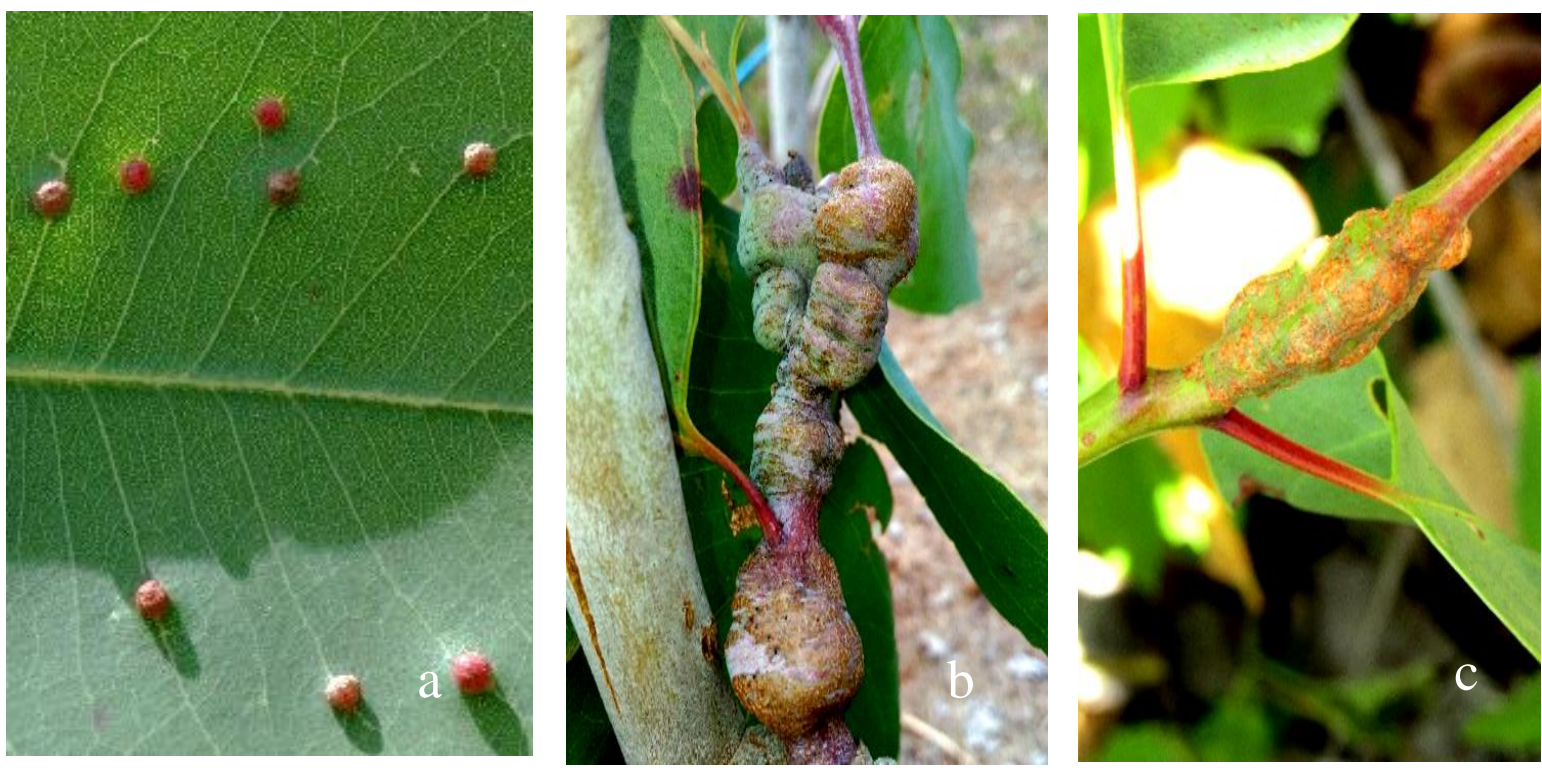

Figure 4 Eucalyptus alba leaf. Galls induced by L. invasa: (a) vein leaves, (b) stem, (c) twig

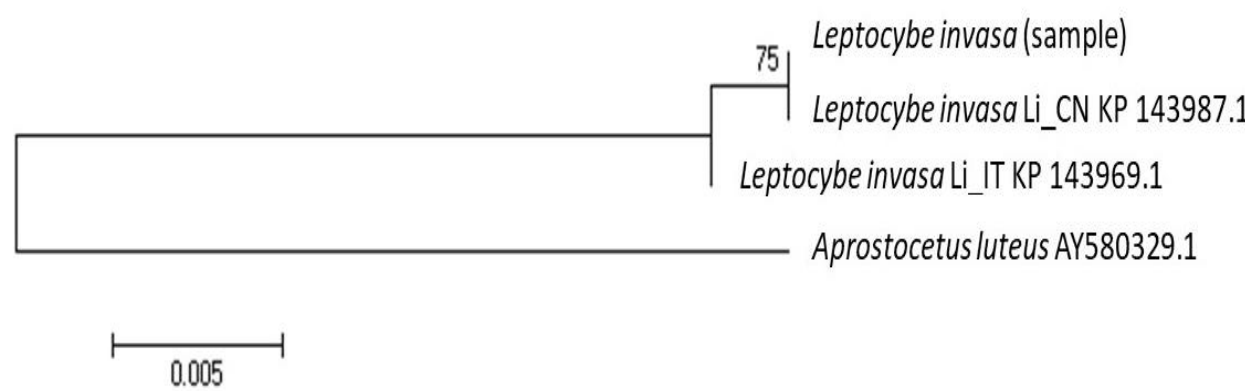

Figure 5 Phylogeny of Leptocybe invasa using software Mega 6 with Neighboorhood joining tree, Boostrap 1000x 
(Hymenoptera: Eulophidae) population intensity and infestation on eucalyptus germplasms in Uganda and Kenya. Int J Pest Manage, 56(2) (2010) 137-144. DOI: http://doi.org /10.1080/ 09670870903248835

[6] C. Jorge, G. Martínez, D. Gómez, M. Bollazzi. First record of the eucalypt gall-wasp Leptocybe invasa (Hymenoptera: Eulophidae) from Uruguay. Bosque, 37(3) (2016) 631-636. http://mingaonline.uach.cl/scielo.php?script=sci_is sues\&pid=0717-9200\&lng=es\&nrm = iso

[7] T.D. Paine, M.J. Steinbauer, S.A. Lawson. Native and Exotic Pests of Eucalyptus: A Worldwide Perspective. Annu. Rev. Entomol. 56 (2011) 181 201. DOI:http://doi.org/10.1146/annurevento120709144817

[8] O. Doganlar. Occurrence of Leptocybe invasa Fisher and La Salle, 2004 (Hymenoptera: Chalcidoidea) on Eucalyptus camaldulensis in Turkey, with a description of the male sex. Zoology in the Middle East, 35 (2005) 112-114.

[9] F. Aytar, Natural biology, distribution and control method of Leptocybe invasa Fisher and La Salle (Hym, Eulophidae), Eucalyptus gall wasp in Turkey. JDOA, 9 (2003) 47-66.

[10] G. Viggiani, S. Laudonia, U. Bernardo. The increase of insect pests in Eucalyptus. (Aumentano gli insetti dannosi agli eucalipti). Informatore Agrario, 58(12) (2002) 86-87.

[11] H.V. Cornell. The secondary chemistry and complex morphology of galls formed by the Cynipinae (Hymenoptera): why and how?, Am. Midl. Nat. 110 (1983) 225-234.

[4] P.Q Thu., B. Dell, T.I.Burgess, Susceptibility of 18 eucalypt species to the gall wasp Leptocybe invasa in the nursery and young plantations in Vietnam. Science Asia, 35 (2009) 113-117.

[5] P. Nyeko, K. E.Mutitu, B.O. Otieno, G.N. Ngae,, R. K. Day.. Variations in Leptocybe invasa 